\title{
Ushul al-Nahwi al-Arabi : Kajian Tentang Landasan Ilmu Nahwu
}

\author{
Rini \\ Institut Agama Islam Negeri Curup \\ rinwan06@gmail.com
}

\begin{abstract}
Nahwu is a very important science in learning Arabic because it contains Arabic rules and grammar. So far there are still many Arabic language learners who have not understood the foundation of the formation of nahwu. This article aims to examine more about the foundation of the established nabwu science. The method used in this study is the library research method, which is a series of activities relating to the method of collecting library data, reading and recording and processing research materials. The results of this study are that the nabwu rules that we have known so far are not necessarily available and available, but have been formulated with hard work and high precision by nahwu experts through four sources are the sama ', ijma', qiyas and istishab.
\end{abstract}

Keywords : ushul, al-nabwu al-'Arabi

\begin{abstract}
Abstrak
Ilmu nabwu merupakan ilmu yang sangat penting dalam pembelajaran bahasa Arab karena berisi tentang kaidah dan tata bahasa Arab. Selama ini para pembelajaran bahasa Arab masih banyak yang belum memahami landasan dari terbentuknya ilmu nahwu. Artikel ini bertujuan untuk mengkaji lebih jauh tentang landasan dari ilmu nabwu yang telah terbentuk. Metode yang digunakan dalam kajian ini adalah metode penelitian kepustakaan, yaitu rangkaian kegiatan yang berkenaan dengan metode pengumpulan data pustaka, membaca dan mencatat serta mengolah bahan penelitian. Hasil dari kajian ini adalah bahwa kaidah-kaidah nabwu yang telah kita ketahui selama ini tidak serta merta ada dan tersedia, namun telah dirumuskan dengan kerja keras dan kecermatan yang tinggi oleh para ahli nabwu melalui empat sumber yaitu sama', ijma', qiyas dan istishab.
\end{abstract}

Kata Kunci: Ushul, al-Nabwi al-Arabi 


\section{Pendahuluan}

Ushul nabwi dapat dikatakan sebagai pondasi tata bahasa Arab. Kedudukannya terhadap nabwu sama seperti kedudukan ushul fiqh terhadap fiqh. Yang pertama meletakan landasan bagi yang kedua. Kedudukan keduanya bisa dianggap lebih tinggi daripada nabwu atau figh, tetapi ushul nabwu tetap bersifat khusus karena berkaitan dengan bidang yang spesifik yaitu, tata bahasa Arab (nahwu).

Ilmu nabwu adalah disiplin ilmu yang bertujuan untuk dapat memahami teks-teks berbahasa Arab, ilmu nabwu dikodifikasi oleh Imam Abu Aswad alDu'aly atas instruksi Imam Ali bin Abi Thalib saat beliau menjabat sebagai khalifah. Ide ini dilatar belakangi oleh beberapa faktor diantaranya faktor agama dan faktor sosial budaya. Dari faktor agama, nabwu memiliki tujuan untuk menjaga al-Qur'an dari kesalahan $(l a h n) .{ }^{1}$ Dari faktor sosial budaya sesungguhnya bahasa tidak dapat dipisahkan dari realitas kehidupan manusia. Bahasa berkembang sesuai dengan berkembangnya kebudayaan manusia itu sendiri. ${ }^{2}$

Dalam sejarah munculnya ilmu nahwu disebutkan bahwa khalifah Ali beserta para tokoh bahasa Arab dan al Qur'an telah menyusun sedikit demi sedikit teori ilmu nahwu yang merupakan cikal bakal munculnya ilmu nahwu. Selanjutnya ilmu nahwu berkembang tahap demi tahap sehingga menjadi suatu ilmu yang sempurna yang mengkaji tata bahasa Arab dan menjadi unsur penunjang bagi siapa saja yang mempelajari bahasa Arab fusha baik dari orang Arab sendiri mapun dari orang non Arab.

Dalam pembelajaran bahasa Arab, ilmu nahwu memiliki peran yang sangat penting terhadap pencapaian dan keberhasilan seorang pembelajaran bahasa Arab, karena ilmu nahwu mengkaji keilmuan tata bahasa Arab itu sendiri. Mengetahui sejarah munculnya ilmu nahwu bagi seseorang yang sedang belajar bahasa Arab akan mempermudah pemahaman terhadap ilmu nabwu itu sendiri. Karena ilmu nabwu adalah ilmu yang merisi tentang tata bahasa Arab, maka menjadi sangat penting untuk dilakukannya kajian berkaitan dengan landasan ilmu nabwu yang slah satunya berisi tentang sumber dari ilmu nabwu itu sendiri.

Ushul nabwi sangat penting dipelajari oleh para pembelajaran bahasa Arab, karena ia merupakan landasan dan epistemologi nabwu. Dalam ushul nabwi dibahas mengenai sumber-sumber, dalil-dalil dan prinsip penemuan nabwu serta mengkaji berbagai perbedaan pendapat di kalangan nubat. ${ }^{3}$ Dalam artikel ini penulis bertujuan melakukan kajian tentang landasan yang melahirkan ilmu

\footnotetext{
${ }^{1}$ Muh. Haris Zubaidillah, Pengantar Ilmu Nabwu belajar bahasa Arab sampai bisa ( $\mathrm{Al}$ Muntai : Hemat, 2018), hlm. iii.

${ }^{2}$ Ummi Nurun Ni'mah, Qiyas sebagai sebuab Metode dalam Nabwu, jurnal Adabiyat : jurnal bahasa dan Sastra, 2008.

${ }^{3}$ M. Thoriqussua, al Sama' Kajian Epistemologi Imu Nabwu, Jurnal Pusaka, jurnal al Qolam.ac.id, ed. 5., 2015.
} 
nahwu. Metode penelitian yang digunakan dalam kajian ini adalah metode penelitian kepustakaan (library research), yaitu rangkaian kegiatan yang berkenaan dengan metode pengumpulan data pustaka, membaca dan mencatat serta mengolah bahan penelitian.

\section{Hasil dan Pembahasan}

Ushul nabwi dapat dipahami sebagai ilmu yang membahas nahwu secara universal baik dari segi kaidah-kaidahnya, dalil-dalilnya, metode istinbat dengan dalil-dalil, maupun dalam bentuk aplikasinya. ${ }^{4}$ Dari perkembangan ushul nabwi banyak terinspirasi dari wacana keilmuan yang telah dikembangkan oleh ulama ushul figh dan ulama fiqh. Seperti halnya dalam sumber hukum yang telah disepakati oleh ulama fiqh yaitu al-Quran, sunnah, qiyas, dan ijma' dalam penetapan kaidah-kaidah fiqh.

Berbicara tentang sumber ilmu nahwu (ushul nahwu) Ibnu Jinni mengatakan bahwa ushul nahwu ada tiga yaitu sama', ijma' dan qiyas. Sedangkan Ibnu al-Anbari mengatakan bahwa ushul nabwi adalah naql, qiyas dan istihabul hal. Dari pendapat para ulama ini dapat kita simpulkan bahwa ushul nahwi ada empat yaitu sama' atau naql, ijma', qiyas dan istibabul hal.

\section{A. Sama'}

Sama' merupakan istilah yang digunakan oleh Suyuthi sedangkan ibnu alAnbari menggunakan istilah naql. Kedua istilah ini pada hakekatnya sama. Ibnu al-Anbari menggunakan istilah naql karena membagi sumber nabwu dan berpandapat bahwa sumber nahwu terbagi menjadi dua yaitu sumber manqul dan sumber ma'qul. Sumber manqul adalah meliputi sumber nahwu yang berasal dari al-Qur'an dan hadits nabi, serta perkataan orang Arab baik berupa prosa maupun syair. Sedangkan yang terkategori sumber ma'qul adalah qiyas, istibabul hal dan seterusnya.

Istilah sama' setidaknya digunakan dalam dua konteks, yaitu pertama, pembuatan atau penggunaan bentuk kata yang didssarkan kepada apa yang biasa digunakan oleh orang Arab dan didengar dari orang Arab dan kedua adalah penggunaan metode pembakuan kaidah nahw melalui proses penelusuran, penyimakan, pencatatan langsung dari fushaha al-Arab. ${ }^{5}$

Sama' atau naql merupakan sumber pertama dari ushul nabwi sebagaimana dalam ushul fiqh yaitu al-Qur'an dan sunnah. Ibnu al-Anbari mendefinisikan bahwa sumber naql adalah perkataan orang Arab yang fasih dan

\footnotetext{
${ }^{4}$ Muhib Abdul Wahab., Pemikiran Linguistik Tammam Hasan dalam Pembelajaran Babasa Arab (Jakarta:UIN Press Jakarta, 2009), hlm. 35.

${ }^{5}$ M. Thoriqussua, al Sama' Kajian Epistemologi Ilmu Nahwu, Jurnal Pusaka, jurnal al Qolam.ac.id, ed. 5., 2015.
} 
tidak termasuk perkataan orang-orang non Arab seperti para maulidin dan lain sebagainya serta yang tidak terdapat syaz: Selanjutnya Suyuthi membatasi pengertian sama' dan mengatakan bahwa yang dimaksud dengan sama' adalah perkataan Arab yang tidak diragukan kefashahan-nya yang meliputi firman Allah Swt yaitu al-Qur'an, perkataan Rasulullah serta perkataan orang Arab sebelum diutusnya Rasulullah, pada masa Rasulullah serta setelahnya hingga terjadinya kerusakan lisan karena banyaknya maulidin, baik berupa nadžm maupun nasr dari muslim maupun kafir. ${ }^{7}$

Alasan dipilihnya naskah sastra sebagai sumber nabwu karena naskahnaskah tersebut terdokumentasikan dan karena fenomena bahasa di dalamnya lebih nyata serta jauh dari apa yang terjadi pada bahasa pergaulan sehari-hari yang memiliki kekurangan dan kekacauan yang biasanya terjadi karena adanya konteks pembicaraan atau lemahnya perhatian pendengar. Tujuan utama mereka sebenarnya adalah ingin menggunakan bahasa al-Qur'an serta memahami strukturnya untuk mengungkap keagungan maknanya. Dan al-Qur'an merupakan nash yang memiliki nilai sastra tinggi dan tidak dapat dipahami bahasanya kecuali dengan nash sastra. ${ }^{8}$

Ibnu al-Anbari telah mensyaratkan bahwa sumber naql harus dari perkataan Arab dan tidak termasuk didalamnya para maulidin karena mereka berada pada tingkatan keempat dari golongan para sastrawan Arab, sebagaimana al-Baghdadi mengatakan dalam kitab Khizanah al-Adab membagi sastrawan Arab kepada empat golongan yaitu sastrawan jahiliyah (sastrawan yang hidup sebelum agama Islam dan wafat sebelum diutusnya Rasulullah), mukhdharamain (orangorang yang hidup pada masa Islam dan jahiliyah), mutaqoddimin (para sastrawan muslim), serta maulidin. ${ }^{9}$

Selanjutnya Ibnu al-Anbari juga mensyaratkan bahwa perawi manqul harus melebihi batas minimal dan batas maksimal yang dibagi menjadi dua bagian. Pertama, mutawatir dengan syarat jumlah perawinya yang tidak memungkinkan mereka untuk sepakat berbohong seperti pada bahasa al-Qur'an dan hadis mutawatir begitu juga perkataan orang Arab. Dan al-Anbari membatasi jumlah perawi maksimalnya adalah 313 perawi. Kedua, abad (perawinya satu), dengan syarat bahwa perawinya tersebut adalah $A d l$, laki-laki maupun perempuan, baik merdeka atau hamba sahaya.

${ }^{6}$ Mahmud Ahmad Nahlah, Ushul al Nahwi al 'Arabiy (Beirut : Daar al Ma'rifah al jaami’ah, 2002), 31.

7 Mahmud Ahmad Nahlah, Usbul al Nahwi al 'Arabiy (Beirut : Daar al Ma'rifah al jaami'ah, 2002), 32.

${ }^{8}$ Mahmud Ahmad Nahlah, Ushul al Nabwi al 'Arabiy, 31.

${ }^{9}$ Lihat al Baghdadi, Kbizanah al-Adab Wa Lubbu al-Bab Lisan al-Arab, tahqiq : Abdus salam Harun, (Kairo: tp, 1967), 1/6. 
Ibnu al-Anbari dan Suyuthi sepakat bahwa yang termasuk naql atau sama' terdiri dari 3 sumber utama yang menjadi dasar qoth'i dalam ilmu nabwu yaitu al Qur'an, Sunah/hadits, perkataan Arab baik syair maupun prosa.

\section{1. al-Qur'an}

Para ulama tidak memiliki perbedaan pendapat terhadap kehujjahan alQur'an, dan sepakat bahwa al-Qur'an merupakan perkataan arab yang paling fasih dan paling dapat diyakini kebenarannya, jauh dari penyimpangan dan menggunakan bahasa Arab yang jelas. Para ahli nahwu mendefinisikan al-Qur'an adalah kalamullah yang diberlakukan pada perkataan manusia, sehingga manusia berbicara dengan bahasa Arab dan al-Qur'an diturunkan dengan bahasa Arab. Bukti penggunaaan al-Qur'an terdapat dalam buku-buku nabwu Sibawaih yang menuliskan bukti al-Qur'anul Karim yang dipadukan dengan perkataan orang Arab baik berupa syair maupun prosa. Sibawaih terkadang memulainya dengan al-Qur'an, terkadang dengan syair atau prosa dan tekadang pula dengan contoh yang diqiyaskan kepada perkataan orang Arab.

Sibawaih dan ulama setelahnya tidak hanya berhenti pada bukti nash alQur'an yang telah distandarkan saja, bahkan mereka juga mengkaji cara membacaranya. al-Qur'an dan bacaan al-Qur'an memiliki perbedaan sebagaimana yang dikatakan oleh Zarkasyi dalam kitab al Burhan bahwa alQur'an adalah wahyu yang diturunkan kepada Nabi Muhammad Saw secara jelas dan merupakan mukjizat. Sedangkan bacaan al-Qur'an adalah perbedaan pelafazan wahyu baik secara tulisan maupun lisan. Hal ini terjadi karena terdapatnya berbagai macam cara dalam melafazkan dan adanya kaidah cabang yang bertentangan dengan kaidah asli, sehingga membuka peluang terjadinya bab jawaz, dalam nahwu, yaitu bab yang berisikan perbedaan dan perdebatan.

Pada hakekatnya seeorang yang memberikan kesaksian terhadap suatu bacaan tidak memiliki kesalahan, akan tetapi ia berusaha menghadirkan dalam bentuk yang berbeda dari dialek Arab yang ada. Dan selanjutnya hal ini mempengaruhi kesaksiannya yang dianggap syaz (cacat) apabila menyimpang dari qiyas yang telah diketahui, dan manakala bacaannya berbeda maka akan ditolak. Beberapa contoh perbedaan bacaan al-Qur'an seperti bacaaan Ibn Amir "kun fayakuna" tidak dibaca dengan nasab, demikian juga bacaan Hamzah yang membaca "wattaqullaballaæi tasaalu bibi wal arbami" yang dibaca jar pada kata arbami karena mengikuti harf jar sebelumnya. ${ }^{10}$

Dalam sama' lafadz atau qiro'at yang didapat harus memenuhi syarat beberapa syarat antara lain:

a. Riwayatnya harus benar berasal dari Rasulullah secara mutawatir

b. Harus cocok atau tidak bertentangan dengan bahasa Arab (kaidah nabwu)

${ }^{10}$ Mahmud Ahmad Nahlah, Ushul al Nahwi al 'Arabiy, 33-35. 
c. Harus sesuai dengan rasm mushaf 'utsmani. ${ }^{11}$

\section{Hadis Rasul}

Hadits menjadi sumber nabwu yang kedua setelah al-Qur'an sebagaimana yang ada juga pada ilmu usbul Fiqh. Alasan menjadikan hadits sebagai sumber kedua setelah al-Qur'an adalah karena petunjuk al-Qur'an yang memerintahkan untuk mentaati Rasulullah dan fungsi hadits sebagai penjelasan terhadap ayatayat al-Qur'an sebagaimana yang telah termaktub dalam al-Qur'an.

Para ahli nabwu sepakat bahwa Rasulullah adalah orang yang paling fasih, dan hadits apabilah riwayatnya shahih dan bahwa Rasul benar-benar mengatakannya maka tidak ada keraguan dan alasan untuk menolaknya.

Akan tetapi beberapa ahli nabwu baik pada zaman dahulu maupun sekarang tidak menjadikan hadits sebagai sumber nabwu yang diambil hukum/kesimpulan darinya lalu menetapkan hukum, namun hadits dijadikan sebagai penguat terhadap bukti yang ditunjukkan oleh al-Qur'an atau perkataan orang Arab.

Oleh sebab itu, para ulama nabwn dalam menyikapi hadits sebagai sumber nabwu terbagi menjadi tiga golongan, yaitu golongan yang melarang menjadikan hadits sebagai sumber nahwu, golongan yang membolehkan, serta golongan tengah.

Syaikh Muhammad al-Khadhri Husain memberikan kesimpulan bahwa kategori hadits yang tidak boleh diperdebatkan untuk dijadikan bujjah dalam bahasa ada 6 , yaitu :

a. Hadis yang diriwayatkan untuk menunjukkan kefasihan Rasulullah Saw.

b. Hadis yang meriwayatkan tentang perkataan dalam ibadah seperti lafadz qunut, tabiyyat dan sebagainya

c. Hadis yang menjadi bukti bahwa Rasulullah berkata kepada kaum Arab sesuai dengan bahasanya.

d. Hadis yang diriwayatkan degan berbagai macam cara, namun lafadznya tetap sama.

e. Hadis yang telah ditulis oleh orang Arab yang tumbuh dalam lingkungan Arab yang tidak rusak bahasanya seperti Malik bin Anas, Abdul Malik bin jarih serta Imam Syafi'i.

f. Hadis yang diketahui melalui rawinya bahwa ia mendapatkan hadits tersebut secara makna. ${ }^{12}$

11 Tamam Hasan, al Ushul, dirasat estimologi li Ushul al Fiker al Lughowi al 'A rabi, 104.

${ }^{12}$ Mahmud Ahmad Nahlah, Ushul al Nabwi al 'Arabiy, 55-56. 
Majma' Lughah al-Arabiyah telah menetapkan beberapa hal berkaitan dengan pendapat Syeikh Muhammad al-Khudri Husain yang membolehkan menggunakan hadits sebagai bujah. Beberapa ketetapan tersebut antara lain:

a. Tidak diperbolehkan berhujjah dengan hadits yang tidak terdapat dalam kitab yang ditulis pada masa generasi hadits pertama seperti kitab hadits kutubus sittah.

b. Berhujjah dengan hadis-hadis dalam kitab ini hanya untuk hadis yang mutawatir dan masybur, hadis yang lafadznya digunakan dalam ibadah, hadits yang diriwayatkan untuk menjelaskan bahwa Rasulullah berbicara dengan setiap kaum menggunakan bahasanya, hadits yang diketahui keadaan rawinya tidak meriwayatkan hadits maknawi, seperti Qasim ibn Muhammad, Raja' bin Haya dan Ibn Sirin, serta hadits yang diriwayatkan dengan berbagai macam cara namun lafadznya satu. ${ }^{13}$

\section{Perkataan Orang Arab}

Perkataan orang Arab merupakan sumber ketiga dari ushul nabwi yang pertama sama'. Maksud dari perkataan orang Arab adalah perkataan orang Arab berupa syair atau prosa sebelum datangnya Islam maupun setelahnya hingga terjadinya kerusakan bahasa yang disebabkan oleh adanya al-muwallad dan tersebarnya lahn dalam bahasa Arab.

Pengertian dari perkataan orang Arab adalah perkataan orang Arab yang fasih walaupun berasal dari anak kecil dan orang gila karena jarah wa ta'dhil tidak berdasarkan kepada kefasihan orang yang menyebutnya namun berdasarkan periwayatan. ${ }^{14}$

Orang orang dikenal lebih pintar dalam syair daripada prosa, karena syair merupakan kekayaan intelektual orang Arab. Melalui syair orang Arab mengetahui para pendahulu mereka, hafal nasab keturunan mereka, hati selalu semangat, akal fikiran yang kuat ingatannya dan lisan yang dhabit (disiplin). Sehingga ada sebuah ugkapan yag mengatakan bahwa "tidak ada orang Arab yang mampu berbicara menggunakan bahasa prosa lebih baik dari syair, mereka tidak hafal prosa walaupun banya 10 prosa, namun mereka tidak lupa dengan syair walaupun banya 10 syair".

Ketika para ulama bahasa ingin mengumpulkan materi bahasa berupa prosa untuk kemudian ditarik kesimpulan kaidah dan hukum, maka mereka akan mengumpulkannnya dari sumber aslinya lalu mereka akan menetapkan tempat dan waktunya.

Untuk tempat dilakukan dengan dua cara yaitu mengambil dari orang Arab badiyah dan mengambilnya dari fushaha' al-hadhar (Irak). Sedangkan

\footnotetext{
${ }^{13}$ Mahmud Ahmad Nahlah, Ushul al Nahwi al 'Arabiy, 56.

${ }^{14}$ Tamam Hasan, al Ushul, dirasat estimologi li Ushul al Fiker al Lughowi al 'Arabi, 107.
} 
mengenai penetapan waktu sekitar 300 tahun, yaitu 150 tahun sebelum Islam dan 150 tahun setelah datangnya Islam.

Penyair Arab terbagi menjadi beberapa tingkatan, yaitu:

a. Thabaqat al Jabiliyyah: mereka adalah para penyair yang hidup pada masa jahiliyah dan belum mengenal Islam, seperti Amr al Qaisy dan al Nabighah

b. Thabaqat al Mukhdharamin: mereka adalah para penyair yang hidup pada masa jahiliyah dan mengenal Islam, seperti lubaid, Hassamn bin bin Tsabit

c. Thabaqat al Mutaqaddimin: disebut juga Islamiyyun yaitu para penyair yang hidupmasa masa Islam dan tidak mengenal masa jahiliyah, seperti Jarir dan Farzadaq.

d. Thabaqat al Muwalladin: disebut juga al Mubadditsun yaitu penyair yang datang setelah para penyair al Mutaqaddimin, seperti Basyar bin Bard dan Abi Nawas. Sebagian ulama menambahkan pembagian penyair Arab menjadi dua kelompok :

a) Thabaqat al Mubadditsin: yaitu para penyair yang datang setelah para penyair al Muwalladin, seperti Abi Tamam.

b) Thabaqat al Mutaakhirin: yaitu para penyair setelah masa al-Mubadditsin, seperti Abi Tamam. ${ }^{15}$

Para ahli nahwu menolak syair yang berasal dari thabaqat keempat dan setelahnya yaitu thabaqat al-muwalladin, al-mubanditsun dan mutaakhirin sebagai sumber nabwu.

Kaidah para ahli bahasa dan ahli nahwu dalam membatasi sumbersumber bahasa Arab yang didengar langsung dari orang Arab serta beberapa kriteria yang ditetapkan, dimaksudkan sebagai kehati-hatian dalam menyimpulkan fenomena bahasa (nahwu) dari bahasa Arab.

\section{Bahasa Fushah dan Dialek-dialek Arab}

Sebagian besar para linguis Arab berpendapat bahwa yang dimaksud dengan bahasa fushah adalah dialek Quraisy atau bahasa Quraisy, orang Arab mengambil bahasa Quraisy sebagai bahasa fushah karena bahasa Quraisy merupakan bahasa suatu kabilah yang besar dan dalam sejarah tercatat bahwa kabilah Quraisy memiliki peran penting pada masa jahiliyah yang mana banyak kabilah Arab lainnya menggunakan dialek Quraisy sebagai bahasa mereka. Diantaranya adalah masyarakat sekitar ka'bah dan pada kota makkah terdapat pasar 'ukaaz, yang terkenal dengan aktivitas sastranya. Namun, terdapat beberapa perbedaan antara kajian Arab dan kajian keislaman, diantaranya adalah:

a. al-Qur'an diturunkan dengan menggunakan bahasa Arab dan bukan diturunkan dengan menggunakan bahasa Quraisy

${ }^{15}$ Mahmud Ahmad Nahlah, Ushul al Nahwi al 'Arabiy, 66-67. 
b. al-Qur'an diturunkan dengan tujuh huruf dengan qiro'at yang beragam, kebanyakan dari qiro'at ini menunjukkan suatu fenomena bahasa yang bukan dialek Quraisy, hal ini mengindikasikan bahwa al-Qur'an bukan hanya menggunakan bahasa Quraisy saja, namun bahasa Arab dari kabilah-kabilah lainnya juga.

c. Sebagaimana diketahui bahwa dialek Quraisy memiliki karakteristik yang tidak digunakan dalam bahasa Arab.

d. Naskah sastra jahiliyah yang ada tidak semuanya menggunakan bahasa Quraisy, sebagian syair menggunakan bahasa kabilah Arab dari utara, selatan, hijaz dan Najd.

e. Rasulullah tidak memandang bahasa Quraisy sebagai bahasa seluruh bangsa Arab, Rasulullah tatkala mendatangi suatu kabilah, maka Rasulullah akan berbicara menggunakan bahasa kabilah tersebut.

f. Para ahli nahwu tatkala menetapkan kriteria kabilah yang termasuk fashahah dan menjadikan bahasanya sebagai sumber nabwu Arab tidak membatasi pada bahasa Quraisy, tetapi mendapatkannya juga dari kabilah Hijaz dan Najd. ${ }^{16}$

Dalam sama' ada dua hal yang harus diperhatikan :

Pertama : bahwa koneksitas terbatas pada pengumpulan bahasa dari orangorang Arab yang berdekatan (dari enam kabilah yang berada di tengah jazirah Arab (tamim, qiis, dll) dan mengambil sedikit dari bahasa kabilah yang fasih yang berdekatan dengannya. Ahli nahwu talah membatasi tempat dan waktu pengumpulannya yaitu sekitar akhir abad ke-2 $\mathrm{H}$ untuk orang Arab perkotaan atau abad ke-4 $\mathrm{H}$ untuk orang Arab pedalaman

Kedua : Ahli nabwu harus menetap di hadapan kabilah yang memiliki bahasanya, mengamati, meneliti secara mendalam sehingga mencapai suatu kesimpulan kepada kaidah nabwu ${ }^{17}$

\section{B. al-Ijma'}

Ijma dalam istilah ulama ushul adalah kesepakatan para mujtabid dari umat Nabi Muhammad Saw dalam suatu masa setelah wafatnya Rasulullah Saw terhadap suatu hukum syari'at. Maksud kesepakatan disini adalah kesepakatan terhadap satu perkara. Tidak ada ijma' yang dilakukan oleh satu orang ulama, jadi syarat kumpulan mujtahid menjadi syarat terjadinya $i j m a{ }^{, 18}$

Ulama ushul membedakan antara ijma hukum syar'i dan ijma lubgawi. Ijma' hukum syar'i berbicara tentang hukum agama antara halal dan haram,

16 Tamam Hasan, al Ushul,dirasat estimologi li Ushul al Fikr al Lughowi al 'Arabi (Daar al tsaqofah, tt), 78-79.

${ }^{17}$ D. Hidayat, al ushul,Dirasat Estimologi li nahwi, fiqh lughah wa balaghah (2008), 24.

18 Mahmud Ahmad Nahlah, Ushul al Nabwi al 'Arabiy (Beirut : Daar al Ma'rifah al jaami’ah, 2002), 77. 
kewajiban dan larangan. Sedangkan ijma' hukum lughawi berbicara seperti hukum jar khusus untuk asma' tidak ada jar untuk fi'il, ini merupakan ijma' lughawi yang disepakati oleh ulama ushul nahwu. ${ }^{19}$

Ijma' lughawi terbagi menjadi tiga jenis, yaitu:

a. Ijma' Ruwat yaitu kesepatan yang terjadi pada orang yang meriwayatkan terhadap suatu riwayat tertentu karena adanya bukti.

Ibn al-Anbari telah menyebutkan bahwasannya ia telah menolak ahli nabwu Kufah yang mengatakan bahwa kata kamaa bermakna sama dengan kata kiimaa dan melarang menashabkan setelahnya. Sedangkan kaum Kufah berpendapat demikian karena ada bukti dari perkataan Addiy bin Zaid alIbadiy.

b. Ijma' orang Arab yaitu ijma' yang terjadi pada orang Arab yang juga dapat dijadikan bujjah. Asy-Suyuthi memaparkan adanya ijma' orang Arab selain ahli nabwu dan rawi dan ijma' orang Arab dapat dijadikan sumber nabwu, seperti adanya orang Arab yang berbicara dengan satu bahasa dan bisa difahami dan mereka sepakat.

c. Ijma' ahli Nabwuyaituijma' yang terjadi antara ahli nabwu yang terdapat di kota Bashrah dan Kuffah. Diantara beberapa contoh ijma antara ahli nabwu Bashrah dan Kufah adalah :

1) Dalam persoalan perselisihan tentang asli isytiqoq kata اسم para ulama Kufah dan Bashrah telah sepakat bahwa hamzah di awal kata ism adalah hamzam ta'wid.

2) Dalam persoalan perbedaan tentang i'rob dari asma' sittah, mereka sepakat bahwa harakat asma' sittab mu'rob.

3) Dalam persoalan mendahulukan khabar dari mubtada', mereka berpendapat bahwa boleh mendahulukan khabar dari mubtada, seperti dalam kalimat ضرب غلامَه زيد.

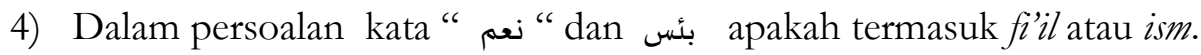

5) Dalam persoalan huruf mim pada kata اللهم apakah dia iwadh dari huruf nida' atau bukan, mereka sepakat bahwa asli katanya adalah يالله الله

6) Dalam persoalan apakah boleh fi'il madhi sebagai haal, sebagaimana kesepakatan bahwa fi'il madhi boleh bermakna sebagai fi'il mustaqbal manakala fïll madhi berfungsi sebagai sifat yang menyifati kata yang tersembunyi (mabdruf).

7) Persoalan 'irab fi'il mudhari', aliaran Kufah dan aliran Bashrah sepakat bahwa fi'il mudhari' adalah mu'rab.

8) Dan lain sebagainya. ${ }^{20}$

${ }_{19}$ Mahmud Ahmad Nahlah, Ushul al Nahwi al 'Arabiy (Beirut : Daar al Ma'rifah al jaami'ah, 2002), 79.

${ }^{20}$ Mahmud Ahmad Nahlah, Ushul al Nabwi al 'Arabiy (Beirut : Daar al Ma'rifah al jaami'ah, 2002), 79-81. Pendapat lainnya menyatakan bahwa ijma terbagi menjadi dua yaitu 


\section{Qiyas}

\section{Pengertian Qiyas}

Qiyas menurut para ahli ushul figh merupakan dalil keempat setelah alQur'an, Sunnah dan Ijma'. Apabila seorang mujtahid mendapatkan suatu masalah yang tidak memiliki hukum dalam al-Qur'an dan Sunnah, dan tidak ada ijma', maka ia harus mencari pembanding terhadap hukum yang telah ada kemudian apabila terdapat illat antara keduanya maka hukum bisa diterapkan kepadanya, inilah yang disebut dengan qiyas.

Pengertian qiyas dalam ushul nabwi adalah mengikuti orang Arab tentang metode berbahasa mereka, membawa bahasa kita kepada bahasa mereka dalam hal sumber materi bahasa serta cabang-cabangnya, pengucapan huruf serta cara menyusun kata-kata dan lain sebagainya. Para linguis sepakat bahwa yang pertama kali menggunakan qiyas dalam ilmu nabwu adalah Abdullah bin Abi Ishaq al-Hadhromain, kemudian baru diteruskan oleh al-Khalil dan Sibawaih. Selanjutnya qiyas mengalami perkembangan dan setelah Sibawaih kaidah qiyas semakin sempurna, sebagaimana yang dilakukan oleh Abi Ali al-Farisi. ${ }^{21}$

Qiyas pada ushul nahwu sebagaimana yang dijelaskan oleh Dr. Ali Abul Makarim telah terbagi menjadi dua priode yaitu pertama, periode qiyas istigroi yaitu sejak munculnya ilmu nabwu hingga akhir abad ke-3 H, kedua, periode qiyas syakli sebagaimana yang nampak pada tulisan Abu Ali al-Farisi, Ibnu Jinni, Ibnu al-Anbari dan Suyuti tentang qiyas. ${ }^{22}$

\section{Qiyas Istiqroi}

Lafadz qiyas telah terdapat pada tulisan para ahli nahwu pertama dalam meletakkan dasar-dasar nabwu Arab untuk menjaga lisan Arab dari lahn serta membantu untuk memahami al-Qur'an. Dalam Muqoddimah Abu Aswad alDuali, Ibnu Salam al-Jumahi berkata dalam bukunya Thabaqat Fubul asy-Syu'ara bahwa orang yang pertama kali meletakkan dasar ilmu bahasa Arab, membuka pintunya, menetapkan metodenya serta meletakkan dasar-dasar qiyas-nya adalah Abu Aswad al-Duali bahwa apa yang telah dilakukan oleh Abu Aswad yang dikenal dengan istilah "dzohiroh al-tasyorruf al-irobi" ia gunakan untuk mengkaji nash al-Qur'an. Selanjutlah muncul Abdullah bin Abi Ishaq yang menulis tentang pelajaran nahwu seperti membatasi metode pembahasan nabwu melalui observasi terhadap fenomena bahasa yang timbul, dan melihat latar belakangnya

pertama, ijma' orang Arab, sebagaimana ulama Suyuthi mengatakan bahwa ijma' orang-orang Arab dapat dijadikan sebagai hujjah, kedua, ijma ahli nahwukota Bashrah dan Kufah, dan ia bisa dijadikan hujjah manakala tidak bertentangan dengan sama' atau qiyas. Lihat D. Hidayat, al-Ushul, Dirasat Estimologi Li Nahwi, Fiqh Lughah Wa Balaghah, (2008), 25.

${ }^{21}$ D. Hidayat, al ushul, Dirasat Estimologi li nahwi, figh lughah wa balaghah (2008), 25.

22 Mahmud Ahmad Nahlah, Ushul al Nabwi al 'Arabiy (Beirut : Daar al Ma'rifah al jaami'ah, 2002), 101-102. 
sehingga terdapat syaz: Pada suatu hari Abdullah bin Abi Ishaq ditanya, "Apakah seseorang pernah berkata الصويق الصويق. Dia berkata," Iya, Amru bin Tamim ". Kemudian ia berkata kepada yang bertanya" Apa yang Anda inginkan dengan bertanya ini? Anda dapat menggunakan qiyas dalam nabwu". ${ }^{23}$

Terdapat beberapa riwayat yang mengatakan bahwa Abdullah bin Abi Ishaq adalah orang yang pertama-tama memformulasikan qiyas dan 'ilal. Metode yang ia gunakan adalah dengan menentukan fenomena-fenomena bahasa umum lalu menjadikannya sebagai maqaayiis (perbandingan) yang tidak boleh dilanggar atau bertentangan dengannya, dan senantiasa melakukan pengawasan terhadap penyimpangan, dan diketahui bahwasannya ia sangat menentang Farzadik ketika ia menampakkan dalam syairnya kaidah yang keluar dari fenomena bahasa umum tersebut. Selanjutnya murid Abdullah bin Abi Ishaq yang bernama Isa bin Umar telah memformulasikan secara umum fenomena-fenomena bahasa lalu membentuknya menjadi kaidah wajib yang tidak boleh dilanggar. ${ }^{24}$

Khalil bin Ahmad belajar ilmu nabwu kepada Isa bin Umar sehingga metode qiyas-nya terhadap kaidah umum bahasa Arab dipengaruhi oleh gurunya, sehingga menulis buku yang berjudul al-ghayah fi tashih al-qiyas, wa istikbroj masail al-nabwi wa ta'lilibi. Khalil tidak menulis buku nabwu, namun pendapatpendapatnya terlihat pada buku muridnya Sibawaih yang telah memuat namanya 332 kali dalam bukunya. Kaidah qiyas mengalami perkembangan yang sangat signifikan pada masa Khalil dan Sibawaih, karena mereka tidak hanya berbicara te kaidah umum tentang fenomena bahasa saja, namun mereka juga berbicara tentang "Iftiradh" persoalan-persoalan yang tidak terdapat dalam kalam Arab untuk menerapkan prinsip-prinsip yang telah mereka rumuskan. Hal ini merupakan istiqra', namun istigra' terhadap gambaran yang dirumuskan oleh fikiran dalam naungan beberapa uslub serta membawanya kepada suatu ketetapan hukum terhadap kalam mereka. ${ }^{25}$

Para ahli nabwu lainnya yang juga menggunakan qiyas adalah al-Mubarrid, al-Akhfasy Ali ibn Sulaiman yang memiliki kitab al-Maqayiis, Abu Umar al-Jarami serta Abi Usman al Mazani. Mereka adalah para ahli nahwu dari Basrah.

Sedangkan para ahli nabwu Kufah, mereka juga menaruh perhatian terhadap qiyas, tetapi mereka telah meluaskan pendengarannya dari orang Arab lalu melakukan qiyas terhadap mereka, sehingga al-Kisa’i berpendapat bahwa nabwu seluruhnya adalah qiyas. Namun hal ini ditentang oleh ulama Basrah dan mengatakan bahwa pendapat tersebut telah merusak nahwu dan terlalu meremehkan sama' dan qiyas.

\footnotetext{
${ }^{23}$ Mahmud Ahmad Nahlah, Ushul al Nabwi al 'Arabiy, 102.

${ }^{24}$ Mahmud Ahmad Nahlah, Ushul al Nabwi al 'Arabiy, 103.

${ }^{25}$ Mahmud Ahmad Nahlah, Ushul al Nabwi al 'Arabiy, 105.
} 


\section{Qiyas al-Syakli}

Pada akhir abad ke-3 H dan awal abad ke-4 H telah dilakukan transformasi terhadap pemahaman qiyas tidak lagi berpegang teguh pada fenomena dan qiyas pada umumnya, namun pada masa ini telah mulai mengambil bentuk formal yang bersandar pada pengambilan cabang dari asal karena memiliki 'illat yang sama. ${ }^{26}$ Pengertian qiyas syakli sempurna pada masa Ibn al-Anbari, lalu dilanjutkan oleh Asy-Suyuthi dan Ibn Jinni dalam bukunya alKhashaish.

Ibn al-Anbari memulainya dengan memberikan definisi tentang qiyas secara etimologi dan terminologi. Ibn al-Anbari berkata bahwa qiyas bermakna taqdir (mengira), sedangkan para ulama bahasa bahasa mengatakan qiyas adalah ungkapan untuk perkiraan terhadap suatu hukum cabang berdasarkan hukum asal, atau dengan kata lain membawa hukum cabang kepada hukum asal karena adanya kesamaan illat, menghubungkan hukum asal dengan cabang, atau mengungkapkan sesuatu dengan sesuatu yang lain. ${ }^{27}$

Ibn al Anbari telah menetapkan dalam qiyas terdapat 4 rukun, yaitu:

\section{a. Asli ( المقيس عليه )}

Pengertian dari المقيس عليه adalah hukum-hukum nabwn serta kaidahkaidah yang dirumuskan oleh ahli nahwu setelah mengkaji naskah-naskah Arab, lalu menjadikan sebagian dari hukum dan kaidah tersebut sebagai hukum/kaidah asal yang menjadi rujukan qiyas bagi kaidah lainnya.

Selanjutnya para ahli nahwu membagi perkataan yang disengar dari orang Arab terbagi menjadi 2 macam, yaitu (1) perkataan orang Arab yang berlaku umum, (2) perkataan Arab yang memiliki syaz (cacat). Sebagian ahli nabwu termasuk Ibnu Jinni bahwa mereka tidak membatasi jumlah muthrad (kaidah yang berlaku umum), kalau terdengar dan sampai perkataan orang Arab kepada mereka, maka perkataan tersebut menjadi kaidah nabwu. Namun, apabila perkataan orang Arab tersebut tidak samapai kepada mereka, maka kaidah tersebut termasuk sya\%:

Ibn Hisyam mengatakan bahwa para ahli nahwu tidak hanya membagi apa yang terdengar dari orang Arab kepada al ithrab dan syuzuz saja, tetapi membaginya kepada ghalib, katsir, nadhir, qalil dan muthrad.

\section{b. Cabang (المقيس)}

المقيس terbagi menjadi dua macam, yaitu : 1). Bentuk mufradat yang ghairu al-manqul kepada bentuk mufradat yang manqul. Hal ini terjadi dikarenakan perkembangan bahasa dan dalam rangka memenuhi kebutuhan masyarakat luas

\footnotetext{
${ }^{26}$ Mahmud Ahmad Nahlah, Ushul al Nabwi al 'Arabiy, 110.

${ }^{27}$ Mahmud Ahmad Nahlah, Ushul al Nabwi al 'Arabiy, 111-112.
} 
terhadap bahasa Arab, (2) al Isytiqaq ghairu al Masmu'ab terhadap al Isytiqaq al masmu'ah.

\section{c. Hukum (الحكم )}

Para ahli ushul figh tidak memasukkan hukum sebagai salah satu rukun qiyas, karena hukum merupakan hasil dari qiyas itu sendiri. Namun para ahli ushul nahwu menjadikan hukum sebagai salah satu rukun dari qiyas, sebagaimana perkataan Ibn al-Anbari, setiap qiyas harus memenuhi empat hal, yaitu aslu, far'u, illat dan bukum.

Hukum (الحكم) menurut ahli nabwn terbagi menjadi dua yaitu: 1). hukum/kaidah yang secara tetap digunakan orang Arab lalu diqiyaskan kepadanya, 2). hukum yang ditetapkan setelah dilakukan qiyas dan kesimpulan.

Hukum dalam nabwu tidak hanya bersifat wajib dan larangan saja, namun terbagi menjadi enam macam hukum dalam nabwnyaitu :

1) Wajib: seperti fa'il wajib marfu', terletak setelah fi'il,maf'ul wajib mansub, mudhaf ilaihi harus kasrabdan sebagainya.

2) Mamnu': kebalikan dari apa yang wajib

3) Hasan: sepertirafa' mudhari' yang terletak setelah syaratmadhi

4) Qabih: seperti rafa' mudhari' yang terletak setelah syaratmudhari'

5) Kbilaf al awla: seperti mendahulukan fa'il dalam kalimat ضربغلامهزيدا

6) Jaiz, 'ala sawa': seperti menghapus mubtada' atau khabar atau tetap ada. ${ }^{28}$

\section{d. Fllat (علَة )}

al-Zujaji membagi 'illat menjadi 3 macam, yaitu : ta'limiyyah, qiyasiyyah dan jadaliyah nadzariyah. Selanjutnya al-Suyuthi mengatakan bahwa illat banyak sekali, namun yang secara umum dikenal illat ada 24 macam, diantaranya adalah:

1) Illat Sama’: seperti perkataan امرأةثدياء dan tidak mengatakan رجل أثدى, hal ini hanya didapat dari illat sama'

2) Illat Tasbib: seperti fi'il aslinya mabni, mudhari' menjadi mu'rob karena maknanya menyerupai ism dan mabni sebagian ism karena menyerupai huruf

3) Illat istighna': seperti penggunaan kata تردع dang Arab hanya menggunakan يدع (fi'il mudhari') dan cukup menggunakan ترع نرك untuk fi'il madhi.

4) Illat istitsqal: seperti beratnya melafazkan huruf waw pada kata يعد karena terletak antara ya dan kasrah

5) Illat farq: sebagaimana ketetapan bahwa fa'il marfu' dan maf'ul mansub, fathah nun jamak dan kasrah nun mutsanna.

${ }^{28}$ Mahmud Ahmad Nahlah, Ushul al Nahwi al 'Arabiy, 136. 
6) Illat Taukid: seperti adanya nun taukid khafifah dan tsaqilah pada fi'il amr untuk menguatkan

7) Illat Ta'widh: seperti huruf mim pada kata Allahumma dari huruf nida'

8) Illat Nadzir: seperti kasrah salah satu sukun apabila bertemu pada keadaan jazm

9) Illat Naqidh: seperti nashab untuk kata nakirah dengan laa

10) Illat haml 'alal ma'na: seperti kata mau'idzah karena bermakna al wa'dzu

11) Illat Masyakilab: seperti perkataan سلغلاسلا dan

12) Illat Mu'adalab: seperti nashab jamak muannas salim yang berharakat jaar

13) Illat Mujawarah: seperti berdampingan dhammah pada huruf lam (ل) pada (الحمد لها ) dengan huruf dal

14) Illat Wujub: seperti illat bahwa fa'il marfu' dan lain sebagainya

15) Illat Jawa: seperti ta'lil imalah

16) Illat taghlib: seperti perkataan وكانتمنالقانتين

17) Illat Ikbtishar: seperti tarkhim dan kata وكيك

18) Illat takhfif: seperti pada idgham

19) Illat asl: seperti استحاذ aslinya

20) Illat Aula: seperti fa'il sebelum maf'ul

21) Illat Dalalah hal: seperti kata hilal

22) Illat Isy'ar: seperti jamak kata موسى adalah موسون dengan fathah sebelum waw untuk memberitahu bahwa alif mahd₹ub.

23) Illat tadhad: seperti tawkid dengan mashdar atau dhamir

24) Illat Tabliq ${ }^{9}$

Sebagian para ahli ushul nabwu menyebutkan bahwa untuk melakukan qiyas terdapat 8 cara, yaitu:

1) al-Ijma'

2) al-Nash

3) al-Iima'

4) al-Sibru wa taqsim

5) al-Munasabah

6) al-Syibhu

7) al-Thardu

8) Ilgha' al-Fariq ${ }^{30}$

\section{Istishab}

Istishab merupakan terminologi yang diperkenalkan oleh pakar nahwu sejak pertumbuhan nahwu dan sejak mereka memperkenalkan kaidah-kaidah

\footnotetext{
${ }^{29}$ Mahmud Ahmad Nahlah, Ushul al Nahwi al 'Arabiy, 129-131.

${ }^{30}$ Mahmud Ahmad Nahlah, Ushul al Nabwi al 'Arabiy, 132.
} 
primer dan sekunder. ${ }^{31}$ Kata Istishab secara etimologi berasal dari kata "istashhaba" dalam sighat istif”ala استفعال yang bermakna استمرار الصحبة kalau kata Siartikan dengan teman atau sahabat dan استمبر diartikan selalu atau terusmenerus, maka istishab secara lughawi artinya selalu menemani atau selalu menyertai, pengakuan adanya perhubungan.

Istishab mengandung pengertian kembali merujuk kepada ketentuan asal dalam masalah-masalah nahwu yang tidak terapat dalam ketiga ushul lainnya. ${ }^{32}$ Menurut Ibnu Jinni al-istishab adalah keluarnya kalam dari arena cakupannya karena tidak ada dalil yang menunjukan makna yang dimaksud.

Dari defenisi diatas dapat ditarik kesimpulan bahwa para ulama nabwn mengatakan bahwa al-istihab itu adalah kembali kepada makna asal kata dan asal penggunaannya selama tidak ada alasan yang merubah makna.

Istishab bisa digunakan selama tidak ada kaidah lain yang menghukumi, namun istishab tidak selalu bisa diterapkan. Oleh sebab itu para ulama ushul nabwu berbeda pendapat dalam menggunakan istishab sebagai sumber ilmu nabwu. Ibn Jinni berpendapat bahwa sumber nahwu hanya tiga yaitu, sama' ijma dan qiyas. Demikian juga dengan Ibn al-Anbari.

Istishab terjadi pada suara, kata dan kalimat. Terdapat dua bagian dalam istishab yaitu, pertama, Asl al-Wadb'i (makna asal) atau disebut juga kaidah asli, kedua, al-udul (lafadz yang dikembalikan ke kaidah asli). Contohnya adalah kaidah asli dalam kalimat bahasa Arab bahwa kalimat terdiri dari mubtada' khabar untuk jumlah ismiyah dan terdiri dari fi'il dan fail untuk jumlab filiyah. Selanjutnya dalam kalimat boleh al-udul (tidak mengikuti kaidah dasar) dengan syarat tetap menjaga manfaatnya dan tidak membingungkan. Contoh lainnya adalah kaidah rafa al-fa'il dan mubtada' serta mendahulukan mubtada' dari khabar, boleh al-udul (penyimpangan dari kaidah asal) dengan tetap menjaga manfaatnya dan tidak membingungkan. Al-udul ada yang tetap dan tidak tetap. al-udul yang tidak tetap ahli nahwu menyebutnya dengan syad 2 , dhoruroh, qalil, nadir atau salah. ${ }^{33}$

Kalimat yang mengikuti kaidah asal tidak pernah diperselisihkan oleh ahli nabwu, dan ahli nabwu tidak harus mendatangkan syawabid (saksi) terdapat ketentuan ism fa'il marfu' dan mubtada ma'rifah karena hal ini merupakan kaidah dasar. Syawabid (bukti) dibutuhkan dari al Qur'an, hadits atau perkataan orang Arab terhadap persoalan nabwu yang mana terdapat udul yang bertentangan dengan kaidah dasar. Ahli nahwu mengatakan bahwa istishab adalah dalil yang paling lemah. ${ }^{34}$

${ }^{31}$ Siti Shalihah, al Istishab (sebuah Teori dan praktik prinsip-prinsip nabwn Arab, jurnal al Ittijah, vol. 10, No. 02, 2018.

${ }^{32}$ D. Hidayat, al ushul, Dirasat Estimologi li nahwi, fiqh lughah wa balaghah (2008), 23

${ }^{33}$ D. Hidayat, al ushul, Dirasat Estimologi li nahwi, figh lughah wa balaghah (2008), 26.

${ }^{34}$ D. Hidayat, al ushul, Dirasat Estimologi li nahwi, figh lughah wa balaghah (2008), 26. 
Beberapa contoh penerapanal-istihab pada asal huruf, antara lain:

$$
\text { الأصل في قد تفيد التبوتُ }
$$

"Asal pada buruf قد adalah untuk menyatakan ketetapan" pada asalnya memasuki fiil madhi, contoh :

قد أفلح المؤمنون

Apabila memasukifiil mudari maka maknanya menyatakan sedikit atau ragu/shaq keluar dari makna aslinya kecuali jika fi'il mudari' itu ditakwilkan kepada fiil madhi pada Firman Allah swt :

$$
\text { قد يعلم الله المعوقين منكم والقائلين لإخوانهم هلم إلينا ولا يأتون البأس إلا قليلا }
$$

Maka makna يعلم pada ayat tersebut adalah أعلم.

Sedangkan contoh penerapan al-istihab dalam kaidah, yaitu :

\section{"Asal pada isim itu adalah dii'rab"}

$$
\text { الأصل في الأسماء الإعراب }
$$

Maksudnya semua isim itu dii'rab, kecuali yang menyerupai huruf hukumnya adalah tidak i'rab (mabmi). berkata Ibnu Malik" diantara isim itu ada yang mabni dan ada yang mu'rab, mabni karena menyerupai huruf'

$$
\text { الأصل في الأفعال البناء }
$$

\section{"Asalpada fi'il itu mabni"}

Maksudnya fi'il al-amri dibina berdasarkan al-istihab adapun fi'il mudhari' di i'rab, karena mirip dengan isim dalam hal syakal, berbeda dengan fiil amri yang tidak menyerupai isim maka hukumnya hukum asal.

\section{Penutup}

Untuk mendapatkan suatu bangunan keilmuan yang mapan, maka ushulnabwu menjadi pondasi dalam lahirnya ilmu nabwu. Kaidah-kaidah nabwu yang telah kita ketahui selama ini tidak serta merta ada dan tersedia, namun telah dirumuskan dengan kerja keras dan kecermatan yang tinggi oleh para ahli nabwu melalui empat sumber yaitu sama',ijma', qiyas dan istishab.Walaupun terdapat perbedaan oleh sebagian ahli ushul nabwu dalam menetapkan sumber-sumber nabwu terutama pada istishab, namun secara umum para ahli nahwu menetapkan bahwa istishab merupakan salah satu sumber nahwu, meskipun menjadi sumber yang paling lemah dibandingkan dengan sumber lainnya. 
162 | Arabiyatuna : Jurnal Bahasa Arab, Vol. 3, No. 1, 2019

\section{Bibliografi}

Ahmad Nahlah, Mahmud, Ushul al Nahwi al 'Arabiy. Beirut : Daar al-Ma'rifah aljaami'ah, 2002.

al-Baghdadi, khazanah al Adab wa lubbu al bab lisan al 'Arab, tahqiq : Abdus salam Harun. Kairo" tp, 1967.

Hidayat, al Ushul, Dirasat Estimologi li nahwi, figh lughah wa balaghah, 2008.

Hasan, Tamam, al Ushul, dirasat estimologi li Ushul al Fikr al Lughowi al 'Arabi, Daar al-Tsaqofah, tt.

Kholisin, Cikal Bakal Kelahiran Imu Nahwu.

Nurun Ni'mah, Ummi, Qiyas sebagai sebuah Metode dalam Nabwu, jurnal Adabiyat: jurnal bahasa dan Sastra, 2008.

Siti Shalihah, al Istishab (sebuab Teori dan praktik, prinsip-prinsip nabwn Arab, jurnal al Ittijah, vol. 10, No. 02, 2018.

Thoriqussua, M.,al Sama' Kajian Epistemologi Ilmu Nahwu, Jurnal Pusaka, jurnal al Qolam.ac.id, ed. 5., 2015.

ZubaidillahMuh. Haris, Pengantar Ilmu Nabwu belajar bahasa Arab sampai bisa, Al Muntai : Hemat, 2018. 